\section{B A Institute of \\ YK Business Administration \\ 六下 \\ Karachi \\ Leadership and Ideas for Tomorrow}

Business Review

Volume 11 Issue 2 July-December 2016

7-1-2016

\title{
Organizational citizenship behavior in educational settings in Pakistan
}

Nauman A. Abdullah

Institute of Education and Research (IER), University of the Punjab, Lahore

Follow this and additional works at: https://ir.iba.edu.pk/businessreview

Part of the Educational Leadership Commons

(c) (i)

This work is licensed under a Creative Commons Attribution 4.0 International License.

\section{Recommended Citation}

Abdullah, N. A. (2016). Organizational citizenship behavior in educational settings in Pakistan. Business Review, 11(2), 77-84. Retrieved from https://doi.org/10.54784/1990-6587.1070

This article is brought to you by iRepository for open access under the Creative Commons Attribution 4.0 License and is available at https://ir.iba.edu.pk/businessreview/vol11/iss2/7. For more information, please contact irepository@iba.edu.pk. 


\title{
ARTICLE
}

\section{Organizational Citizenship Behavior in Educational Settings in Pakistan}

\author{
Nauman A. Abdullah \\ Institute of Education and Research (IER), \\ University of the Punjab, Lahore,
}

\begin{abstract}
Organizational citizenship behavior refers to non-paid voluntary activities engaged in by staff of any organization. This article provides a review of the literature on such behaviour in Pakistan.
\end{abstract}

Key Words: Organizational citizenship behaviors, education, Pakistan, antecedents, predictors.

\section{Introduction}

Organizational Citizenship Behavior (OCB) is used extensively in many of the previous research as it has established an effect on the organizational usefulness, in general (Walz\&Niehoff,1996). OCB is sometimes, also, referred to as extra-role behaviors that includes behaviors that go far from the formal job description of the employees. Employees extend their work capacity to all other non-formal roles for which they expect no rewards, recognition, or formal appreciations from the high-ups (Organ,1988). Therefore, it is worthy of interest to understand the defining settings and factors that cause these behaviors in an employee, so that we may know that how these behaviors get stimuli and when they come to action. In their research, LePine, Erez and Johnson (2002) have illustrated that employees show significant organizational citizenship behaviors when their leaders in the organizations show support and interest in them. According to Aquino and Bommer (2003) citizenship behaviors in an organization may increase the societal attractiveness in an organizational workplace as they project positivity. Also when OCB stereotypically characterized as positive behaviors, employees who unveil such behaviors may become more socially attractive and their chances of taken as a friend or a trust worthy partner may rise substantially. Contrary to this, when an employee who never extends his helping hand to colleagues may be seen as aloof and disinterested in the organizational setup of working (Owen, Pappalardo, \& Sales, 2000). One must be clear in defining OCBs as formally defined and outlined behaviors, even if they are performed in an exceptional way, they will not be called as OCBs. However, it should be given due importance that job roles and requirements for higher level positions are more flexible and less formal hence, making it more difficult to draw a line between role behaviors of a job and OCBs (Organ \& Ryan, 1995, p. 791).

In Pakistani context where unemployment still remains an issue, as per Abdullah, Raza, and Akhtar (2015) and only little work has been carried out in respect of the OCBs, especially in the field of education it is minimal. The OCBs in education are considered pivotal throughout the developed countries as the literature reveals positive outcomes and predictions of the OCBs at workplace. This theoretical review article is basically catering the need of compiling the literature of OCB in education in Pakistan as well as critically examining it. This research article will also throw light on the antecedents of OCBs and the consequences of OCBs. The other objective of this review article is to conceive the predictions of the OCBs found relevant and supported in the literature. 


\section{Organizational Citizenship Behavior}

According to Organ (1997) OCB is an "Individual behavior on the basis of "volunteerism"; helping without taking into consideration the formal reward system and it helps in achieving success and output of the institution."

Literature of the recent past highlights OCBs by categorizing the behaviors in two main domains which are known as "role behaviors" and "extra-role behavior". Extra role behaviors are employee contributions in a workplace which are not a part of his designed job description and therefore no rewards are given for them (Owen et al. 2000). According to Castro, Armario, and Ruiz (2004) it is a bit difficult for an organization to differentiate between role behaviors and extra-role behaviors because what upper management or heads think of the performance of their juniors might not conform to their subordinates' perceptions in the organization. Extensive research is carried out to date on the dimensions and factors of OCB. William and Anderson (1991) identified two groups of OCBs which are Organizational Citizenship Behaviors for Individual (OCB-I) and Organizational Citizenship Behaviors for Organization (OCB-O). From a theoretical orientation, making a distinguishing difference in OCB-O and OCB-I is significant because OCB-I fosters the interpersonal facets of the citizenship behaviors and OCB-O emphasizes the view of organizational goals, philosophy, and work citizenship (Spitzmuller, Dyne \& Ilies, 2008). In the past there have been numerous studies highlighting these two groups of OCBs like Mohammad, Habib and Alias (2011) and (Belogolovsky \& Somech, 2010). A big number of research suggest that there are five fundamental factors that affect a majority of the variances in the behavior (Costa \& McCrae, 1992) and these dimensions are categorized as altruism, civil virtue, conscientiousness, courtesy, and sportsmanship. Several recent research in the field of education have used these five dimensions of OCB, the likes of (Abdullah \&Akhtar, 2016; Gonzales \& Wagenaar, 2006; Lo \& Ramayah, 2009; Ehtiyar, Alan \& Omuris, 2010; Mehboob \& Bhutto, 2012; Neeta, 2013; Telghani \& Mehr, 2013; and Unal, 2013).

In educational settings in Pakistan OCBs are studied variedly. A study conducted by Iqbal, Aziz, and Tasawar (2012) viewed the impact of organizational justice on OCB in universities of Pakistan. They concluded that organizational justice does have an impact on the OCBs in educational institutions up to 7.1\%. Nazir, Aslam and Nawaz (2011) while studying the organizational citizenship behaviors in universities of Pakistan, took leadermember exchange (LXM) as a mediating variable and found in their empirical conclusions that LXM only partly arbitrates the relationship of distributive justice and OCBs in teachers. Noor (2009) states in her study that, Pakistan is an under research country in the field of OCBs.

These studies focusing OCBs were concentric to US and UK in the beginning, only recently have OCBs been researched in the international settings including but not limited to Australia, China, Hong Kong, Japan, Singapore, and Taiwan (Chen, Hui, \& Sego, 1998; Hui, Law, \& Chen, 1999: Lam, Hui, \& Law, 1999; Tang, Furnham, \& Davis, 2002; Van Dyne \& Ang, 1998). In Pakistani context, a little research is carried out in organizational citizenship behaviors (Noor, 2009; Naeem, Malik, \& Bano, 2014). A few worth mentioning studies conducted in Pakistan are (Abdullah \&Akhtar, 2016; Aslam, 2012; Iqbal, Aziz, \& Tasawar, 2012; Irshad \& Hashmi, 2014; Nazir, Aslam, \& Nawaz, 2011; Noor, 2009). 


\section{Theoretical Background of OCB}

Norm of reciprocity is a basic fundamental principle considered behind the construct of OCB (Abdullah \&Akhtar, 2016). Norm of reciprocity implies that an employee will do good gestures for others only if he assumes that he will be reciprocated with the same good gestures. Schroeder (2010) explains in his working paper that first, if employees assume that the treatment of their peers, seniors and juniors is fair with them, then according to the norm of reciprocity, the employees would respond positively to them (Blau, 1964). So people perform OCB's in order to give back to the organization, or organizational leader. This explanation is typically associated with the group-value literature, placing heavy emphasis on the quality of the relationship, such that employees are guided to return benefits in order to maintain the social exchange relationship (Cropanzano \& Mitchell, 2005; Cropanzano, Byrne, Bobocel, \& Rupp, 2001). The second thought of reasoning is parallel but somewhat more practical: Since, I am given respect, I might perform exceedingly well considering that my inputs will be compensated in the long-run. By default, these descriptions suggest a trade-off that if an employee suffers in a short run believing that he or she will be rewarded for that sacrifice in the long run for their efforts (Organ \& Moorman, 1993).

\section{Antecedents of OCB}

On critically examining the OCB construct review the researcher identified the following antecedents of OCB based on the studies of (Bateman \& Organ, 1983; Beber \& Rofcanin, 2012; Blau, 1964; Locke, 1976; Motowidlo, 2000; Neuman \& Kickul, 1998; Organ, 1988; Podsakoff \& MacKenzie, 1997) 1) positive attitudes 2) negative attitudes 3) self-serving motives 4) personality 5) leadership 6) task characteristics 7) group and organizational characteristics. Concluding the antecedents, it was observed that job attitudes, task variables, and various types of leader behaviors were more prone to show a relatively substantially positive relationship to OCBs than the other factors. Many other research, the likes of, (Bateman \& Organ, 1983; Moorman, 1991; Moorman, Niehoff, \& Organ, 1993; Organ, 1988; Smith, Organ, \&Near, 1983), narrated that job satisfaction, perceptions of fairness, and organizational commitment were showing a positive correlation with OCBs in an organization.

Task variables are another prominent factor in the antecedents of OCBs as it also shows positive relationship with organizational citizenship behaviors, in spite inconsiderable attention was stressed on them in the OCB literature. Scientific research in the recent past has emphasized four classifications of antecedents of OCBs. According to Podsakoff, MacKenzie, Paine, and Bachrach (2000) these are: individual (employee) characteristics, task characteristics, organizational characteristics, and leadership behaviors. The role of dispositions, attitudes, and motivations as antecedents of OCBs are also found in the work of (Spitzmuller et al. 2008). The Citizenship Motivation Scale (CMS) developed by Riouxand Penner (2001) demonstrated three vital factors as antecedents of OCBs which were; prosocial values; organizational concern; and impression management. Organizational commitment is also found to be a predicting variable for the OCBs in university teachers of Pakistan (Noor, 2009).

Summing up, there is a dire need to research all these antecedent of organizational citizenship behavior in educational settings in Pakistan, in order to establish the contextual grounds of the variables. 


\section{Predictions of OCB}

Upon minutely re-visiting the relevant literature on OCBs and predictions made thereof, it is illustrated that a study conducted by (Abdullah \&Akhtar, 2016) revealed significant prediction of Job satisfaction, empirically, through OCBs, the study is of interest as it revealed data from the varsity teachers of Pakistan. Another study in this regard showed relevant significant prediction of the organizational commitment through OCBs (Mehrabi, Alemzadeh, Jadidi, \& Mahdevar, 2013). It also predicted organizational culture, organizational values, and philosophy of the organization. Performance appraisals is also one of the predictive consequence of the OCB (Johnson, Holladay, \& Quinones, 2009; MacKenzie, Podsakoff, \& Fetter, 1993). According to Johnson et al. (2009) positive OCB in an organization will predict performance appraisals for the employees.

In their empirical research, Chen, Hui, and Sego (1998) concluded that turnover could also be predicted by the level of OCB in an organization. They also suggested that turnover can be reduced if OCB levels are up in any given organization. OCB also helps in predicting the selection process of the educators as well as other professionals in any organization (Podsakoff, Whiting, Podsakoff, \& Mishra, 2011). Impression management is often related to as the originating factor in the OCBs, however, (Farrell \& Finkelstein, 2011; Halbesleben, Bowler, Bolino, \& Turnley, 2010; Hui, Lam, \& Law, 2000) added in the literature through their respective works that OCB may also predict impression management behavior of the employees in an institute.

In a nutshell, literature in Pakistan is still not sufficient to establish prediction patterns of organizational citizenship behaviors. It is recommended to have OCB as an investigating variable in studies both in business and in education disciplines. Concrete research based evidences shall strengthen the prediction patterns of the OCBs.

\section{Discussion}

The purpose of this review article was to minutely study the literature and body of knowledge on the Organizational Citizenship behavior in educational settings in Pakistan. It was also aimed at collecting all the relevant research done so far on OCB in education in Pakistan. The article by scientifically reviewing the research in the recent past has concluded that there is vast literature available in the contemporary world related to the OCBs of employees and teachers in the organizations and institutions. Little work, however, has been done in educational settings in Pakistan. As developing country and still lacking the literacy rate, Pakistani educational institutions require especial emphasis on the OCBs in their educational system. The dropout rate remains an area of grave concern even after years of working on it. The government is taking keen steps to uplift literacy rates, to reduce dropouts, and to give quality education to the masses.

As suggested by the review, OCBs should be encouraged in education sector as they will enhance the behaviors of the teachers not only toward themselves, but also among their students. This will encourage the teacher-student learning process and help the cause. The review further suggested that there is still lot to be covered in organizational citizenship behavior context in educational settings and the predictions made OCBs still need extensive research to establish a strengthened opinion. Relating to the objectives of this paper, the researcher has endeavored to produce extensive literature on the variable making clear distinctions in the antecedents and predictions of the organizational citizenship behaviors. This paper significantly adds to the understanding of the variable and its implications for educational system of Pakistan thus, achieving the prime objective of this research. 


\section{References}

Abdullah, N. A., \&Akhtar, M. M. S. (2016). Job satisfaction through organizational citizenship behavior: A case of university teachers of Pakistan. Alberta Journal of Educational Research, 62(2), 134-149.

Abdullah, N. A., Raza, S. A., \&Akhtar, M. M. S. (2015). Measuring work stress of marketing professionals. Business Review, 10(1), 188-193.

Aquino, K., \& Bommer, W. H. (2003). Preferential mistreatment: How victim status moderates the relationship between organizational citizenship behavior and workplace victimization. Organizational Science, 14(4), 374-385.

Aslam, R. (2012). Investigating the relationship of OCB with job satisfaction organizational commitment and turnover intensions (a case study on teaching staff of university of the Punjab). International Journal of Economics and Management Sciences, 1(9), 90-100.

Bachrach, D., \& Jex, S. (2000). Organizational Citizenship and Mood: An Experimental Test of Perceived Job Breadth'. Journal of Applied Social Psychology, 30(3), 641-663.

Bateman, T. S., \& Organ, D. W. (1983). Job satisfaction and the good soldier: The relationship between affect and citizenship. Academy of Management Journal, 26(4), 587595.

Belogolovsky, E., \& Somech, A. (2010). Teachers' organizational citizenship behavior: Examining the boundary between in-role behavior and extra-role behavior from the perspective of teachers, principals and parents. Teaching and Teacher Education, 26, 914923.

Blau, P. (1964). Exchange and power in social life. New York: Wiley.

Castro, C. B., Armario, E. M. \& Ruiz, D. M. (2004). The influence of employee organizational citizenship behavior on customer loyalty. International Journal of Service Industry Management, 15(1), 27-53.

Chen, X., Hui, C., \& Sego, D. J. (1998). The role of organizational citizenship behavior in turnover: Conceptualization and preliminary test of key hypotheses. Journal of Applied Psychology, 83(6), 922-931.

Costa, P. T. \& McCrae, R. R. (1992). Normal personality assessment in clinical practice: The NEO personality inventory. Psychological Assessment, 4(1), 5-13.

Cropanzano, R., Byrne, Z. S., Bobocel, D. R., \& Rupp, D.E. (2001). Moral virtues, fairness heuristics, social entities, and other denizens of organizational justice. Journal of Vocational Behavior, 58, 164-209.

Cropanzano, R. \& Mitchell, M. S. (2005). Social exchange theory: An interdisciplinary review. Journal of Management, 31, 874-902.

Ehtiyar, V. R., Alan, A. A., \& Omuris, E. (2010). The role of organizational citizenship behavior on university students' academic success. Tourism and Hospitality Management. 16(1), 47-61.

Farrell, S. K., \& Finkelstein, L. M. (2011). The impact of motive attributions on coworker justice. Journal of Business and Psychology, 26, 57-69.

Gonzalez, J., \& Wagenaar, R. (2003). (Eds.) Tuning Educational Structures in Europe. University of Deusto, Spain. 
Halbesleben, J.R.B, Bowler, W.M., Bolino, M.C., \& Turnley, W.H. (2010).Organizational concern, prosocial values, or impression management? How supervisors attribute motives to organizational citizenship behavior. Journal of Applied Social Psychology, 40, 1450-1489.

Hui, C., Lam, S., \& Law, K. (2000). Instrumental values or organizational citizenship behavior for promotion: A field quasi-experiment. Journal of Applied Psychology, 85, 822828.

Hui, C., Law, K., \& Chen, Z. X. (1999). A structural equation model of the effects of negative affectivity, leader-member exchange, and perceived job mobility on in-role and extra role performance: A Chinese case. Organizational Behavior and Human Decision Processes, 77, $3-21$.

Iqbal, H. K., Aziz, U., \& Tasaswar, A. (2012). Impact of Organizational Justice on Organizational Citizenship Behavior: An Empirical Evidence from Pakistan. World Applied Sciences Journal, 19(9), 1348-1354.

Irshad, R, \&Hashmi, M. S. (2014). How transformational leadership is related to organizational citizenship behavior? The mediating role of emotional intelligence. Pakistan Journal of Commerce and Social Sciences, 8(2), 413-425.

Johnson, S.K., Holladay, C.L., \& Quinones, M.A. (2009). Organizational citizenship behavior in performance evaluations: distributive justice or injustice? Journal of Business and Psychology, 24, 409-418

King, E., George, J., \& Hebl, M. (2005). Linking Personality to Helping Behaviors at Work: An Interactional Perspective. Journal of Personality, 73(3).

Ladd, D., \& Henry, R. (2000). Helping Coworkers and Helping the Organization: The Role of Support Perceptions, Exchange Ideology, and Conscientiousness. Journal of Applied Social Psychology, 30(10), 2028-2049.

Lam, S. K., Hui, C., \& Law, K. (1999). Organizational citizenship behavior: Comparing perspectives of supervisors and subordinates across four international samples. Journal of Applied Psychology, 84, 594-601.

LePine, J. A., Erez, A. \& Johnson, D. E. (2002). The nature and dimensionality of organizational citizenship behavior. A critical review and meta-analysis. Journal of Applied Psychology, 87(1), 52-65.

Lo, M. C., \& Ramayah, T. (2009). Dimensionality of organizational citizenship behavior in multi-cultural society: The case of Malaysia. International Business Research, 2(1), 48-55.

Locke, E. (1976). The nature and consequent of job satisfaction. in Dunette, M.D. (ed), Handbook of Industrial and Organizational Psychology, Rand-McNally, Chicago, IL, 12971349.

MacKenzie, S. B., Podsakoff, P. M., \& Fetter, R. (1993). The impact of organizational citizenship behavior on evaluations of salesperson performance. The Journal of Marketing, 57, 70-80.

McCrae, R. R., \& Costa, P. T. Jr. (1987). Validation of the five-factor model of personality across instruments and observers. Journal of Personality and Social Psychology, 52, 81-90.

Mehboob, F., \& Bhutto, N, A. (2012). Job satisfaction as predictor of organizational citizenship behavior. Paper presented at International conference on Business, Economics, Management, and Behavioral Sciences (ICBEMBS). Dubai. 
Mehrabi, J., Alemzadeh, M., Jadidi, M., \& Mahdevar, N. (2013). Explaining the relation between organizational commitment and dimensions of organizational citizenship behavior. Case study: Textile factories in Borujerd countries. Interdisciplinary Journal of Contemporary Research in Business, 5(8), 121-132.

Mohammad, J., Habib. F. Q.\& Alias. M. A. (2011). Job satisfaction and Organizational Citizenship Behavior: An empirical Study at higher Learning Institutions. Asian Academy of Management Journal, 16(2), 149-165.

Moorman, R. H. (1991). Relationship between organizational justice and organizational citizenship behaviors: Do fairness perceptions influence employee citizenship? Journal of Applied Psychology, 76, 845-855.

Moorman, R. H., Niehoff, B. P., \& Organ, D. W. (1993). Treating employees fairly and organizational citizenship behavior: Sorting the effects of job satisfaction, organizational commitment, and procedural justice. Employee Responsibilities and Rights Journal, 6, 209225.

Motowidlo, S. J. (2000). Some basic issues related to contextual performance and organizational citizenship behavior in human resource management. Human Resource Management Review, 10, 115-126.

Naeem, B., Malik, M. E., \& Bano, N. (2014). Nurturing organizational citizenship behaviors by optimism subculture empirical evidence from Pakistan. Pakistan Economic and Social Review Volume, 52(2), 175-186.

Nazir, M. S., Aslam, M. S., \& Nawaz, M. M. (2011). Mediating Role of LMX in Distributive Justice - Organizational Citizenship Behavior Relationship: Evidence from Pakistan. European Journal of Social Sciences, 25(3), 59-68.

Neeta. (2013). Organizational citizenship behavior of faculties in private engineering colleges w.e.flucknow. International Journal of Management and Business Studies, 3(1), 116-123.

Neuman, G. A., \& Kickul, J. R. (1998). Organizational citizenship behaviors: Achievement orientation and personality. Journal of Business and Psychology, 13, 263-279.

Noor, A. (2009). Examining organizational citizenship behavior as the outcome of organizational commitment: a study of universities teachers of Pakistan. Paper presented at CBRC, Lahore, Pakistan.

Organ, D. W., \& Ryan, K. (1995). A meta-analysis of attitudinal and dispositional predictors of organizational citizenship behavior. Personnel Psychology, 48, 775-802.

Organ, D. W. (1997). Organizational citizenship behavior: its construct clean-up time. Human Performance, 10(2), 85-97.

Organ, D. W. (1988). Organizational citizenship behavior: The good soldier syndrome. Lexington Books, MA: Lexington Books.

Organ, D. W., \& Moorman, R. H. (1993). Fairness and organizational citizenship behavior: What are the connections? Social Justice Research, 6, 5-18.

Owen, F. A., Pappalardo, S. J., \& Sales, C. A. (2000). Organizational Citizenship behavior: Proposal for a new dimension in counsellor education. Canadian Journal of Counselling, 34(2), 98-110.

Podsakoff, P. M., \& Mackenzie, S. B. (1997). The impact of organizational citizenship in organizational performance: Review and suggestion for future research. Human Performance, $10,133-151$. 
Podsakoff, P. M., MacKenzie, S. B., Paine, J. B., \& Bachrach, D. G. (2000). Organizational citizenship behaviors: A critical review of the theoretical and empirical literature and suggestions for future research. Journal of Management, 26(3), 513-563.

Podsakoff, N. P., Whiting, S.W., Podsakoff, P. M., \& Mishra, P. (2011). Effects of organizational citizenship behaviors on selection decisions in employment interviews. Journal of Applied Psychology, 96, 310-326.

Rioux, S. M., \& Penner, L. A. (2001). The causes of organizational citizenship behavior: A motivational analysis. Journal of Applied Psychology, 86(6), 1306-1314.

Schappe, S. P. (1998). The influence of job satisfaction, organizational commitment and fairness perceptions on organizational citizenship. The Journal of Psychology, 32(3), 277290.

Schroeder, T. (2010). Explaining Organizational Citizenship Behavior: A Critical Review of the Social Exchange Perspective (working paper).

Smith, C. A., Organ, D. W., \& Near, J. P. 1983. Organizational citizenship behavior: Its nature and antecedents. Journal of Applied Psychology, 68, 655-663.

Spitzmuller, M., Dyne, L. V., \& Ilies, R. (2008). Organizational Citizenship Behavior: A Review and Extension of its Nomological Network. The sage handbook of organizational behavior, 106-123. Barling: Sage.

Taleghani, M., \& Mehr, R. R. (2013). The relationship between servant leadership and organizational citizenship behavior in executive organizations of Gulian province. Journal of Basic and Applied Scientific Research, 3(1), 910-917.

Tang, T. L., Furnham, A., \& Davis, G. M. (2002). The meaning of money: The money ethic endorsement and work-related attitudes in Taiwan, the USA and the UK. Journal of Managerial Psychology, 17, 542-563.

Unal. O. F. (2013). Relationship between the facets of job satisfaction and the dimensions of organizational citizenship behavior: mediating role of organizational commitment. The Journal of Faculty of Economics and Administrative Sciences, 18(1), 243-269.

Van Dyne, L., \& Ang, S. (1998). Organizational citizenship behavior of contingent workers in Singapore. Academy of Management Journal, 41, 692-703.

Walz, S. \& Niehoff, B. P. (1996). Organizational citizenship behaviors and their effect on organizational effectiveness in limited-menu restaurants. Paper presented at Academy of Management Meetings, Cincinnati, $\mathrm{OH}$.

Williams, L. J., \& Anderson, S. E. (1991). Job satisfaction and organizational commitment as predictors of organizational citizenship and in-role behaviors. Journal of Management, 17(3), 601-617. 